\title{
The effects of steroid therapy on the cardiovascular system
}

\author{
Wpływ steroidoterapii na układ sercowo-naczyniowy
}

\author{
${ }^{1}$ Chair and Department of Physiology, Wroclaw Medical University, Wrockaw, Poland. Head of the Department: Professor Beata Ponikowska, MD, PhD \\ ${ }^{2}$ Division of Anatomy, Wroclaw Medical University, Wrocław, Poland. Acting Head of the Division: Zygmunt Domagała, MD, PhD \\ ${ }^{3}$ Department of Urology and Urological Oncology, University Teaching Hospital in Wroclaw, Wrocław, Poland. Head of the Department: Professor Romuald Zdrojowy, MD, PhD \\ Correspondence: Anna Otlewska, Wiązowa 7/1, 53-127 Wrocław, Poland, tel.: +48500 074 744, e-mail: a.otlewska@gmail.com
}

Abstract Glucocorticoids are widely used as anti-inflammatory, antiproliferative and immunosuppressive agents in many diseases. Their use is often long-term, which is associated with the risk of adverse effects from various systems. In this paper, we pay particular attention to the effects of steroid therapy on cardiovascular diseases as long-term steroid therapy increases the risk of cardiovascular death. The risk of complications depends on the dose and therapy duration. Complications may also occur when steroids are used locally. According to literature data, glucocorticoids may contribute to the development of hypertension, myocardial ischaemia, heart failure and, according to some studies, stroke. The use of steroid therapy can lead to the development of disorders that are part of the metabolic syndrome. The pathogenesis includes the effects of glucocorticoids on the renin-angiotensin-aldosterone system, the autonomic system, stimulation of the mineralocorticoid receptor, and effects on the synthesis of factors regulating the width of blood vessels. Other disorders that may develop in the course of this therapy include osteoporosis, myopathy, electrolyte and metabolic disorders. However, it is difficult to determine to what extent the complications are caused by the therapy itself and to what extent by the treated disease. It is also worth noting about the negative impact of anabolic steroids, the use of which is usually not a part of therapy.

Keywords: glucocorticosteroids, cardiovascular diseases, Cushing's syndrome, steroid therapy

Glikokortykosteroidy są powszechnie stosowane w terapii wielu chorób, gdzie wykorzystywane jest ich działanie przeciwzapalne, przeciwproliferacyjne i immunosupresyjne. Często podawane są długotrwale, co wiąże się z ryzykiem wystąpienia działań niepożądanych ze strony różnych układów. W niniejszej pracy zwrócono uwagę przede wszystkim na wpływ steroidoterapii na pojawienie się chorób serca i naczyń, ponieważ długotrwała terapia steroidami zwiększa ryzyko zgonu z przyczyn sercowo-naczyniowych. Stopień ryzyka wystąpienia powikłań zależy od wielkości stosowanej dawki oraz czasu prowadzonej terapii. Nie znika on nawet wtedy, gdy steroidy stosowane są miejscowo. Według danych z literatury przyjmowanie glikokortykosteroidów może przyczyniać się do rozwoju nadciśnienia tętniczego, niedokrwienia mięśnia sercowego, niewydolności serca, a według niektórych badań także do udarów. Stosowanie steroidoterapii może prowadzić do rozwoju zaburzeń będących elementami zespołu metabolicznego. W patogenezie uwzględnia się wpływ glikokortykosteroidów na układ renina-angiotensyna-aldosteron, układ autonomiczny, pobudzanie receptora mineralokortykosteroidowego, wpływ na syntezę czynników regulujących szerokość naczyń krwionośnych. Innymi zaburzeniami, które w przebiegu tej terapii mogą się rozwijać, są: osteoporoza, miopatia, zaburzenia elektrolitowe i metaboliczne. Trudno jednak określić, w jakim stopniu sama terapia wpływa na wystąpienie powikłań, a w jakim choroba, z której powodu stosowane są te leki. Warto również pamiętać o negatywnym wpływie na organizm steroidów anabolicznych, których przyjmowanie zazwyczaj nie jest elementem terapii innego schorzenia.

Słowa kluczowe: glikokortykosteroidy, choroby sercowo-naczyniowe, zespół Cushinga, steroidoterapia 


\section{INTRODUCTION}

G lucocorticoids are widely used in many diseases due to their immunosuppressive $e^{(1)}$, anti-inflammatory and antiproliferative effects ${ }^{(2)}$. According to literature data, long-term steroid therapy is used in about $1 \%$ of population. About $2 / 3$ of patients using long-term steroids show signs of their excess ${ }^{(3)}$. Some researchers believe that adverse effects may occur in up to $90 \%$ of patients receiving steroids for more than 60 days ${ }^{(4)}$. Steroids are used for the treatment of systemic lupus erythematosus, rheumatoid arthritis, asthma, sarcoidosis, inflammatory bowel diseases, nephrotic syndrome $e^{(5)}$, vasculitis and polymyalgia rheumatica ${ }^{(6)}$. Glucocorticosteroids are also used in patients with hypopituitarism. It is important for these patients to choose the lowest needed replacement doses of steroids ${ }^{(7)}$. Cushing's syndrome is a collection of signs and symptoms due to prolonged exposure to cortisol. Symptoms of this syndrome may be caused by either exogenous steroids administered as part of therapy in various diseases or their excessive endogenous synthesis. Most cases are due to exogenous steroids ${ }^{(8)}$. These agents may be administered via different routes, e.g. intramuscular, intravenous, oral, inhalation and topical (transdermal $)^{(9)}$. It is worth adding that topical steroids may also lead to organ adverse effects ${ }^{(10,11)}$, especially when used for a long time on the thin skin and inflamed areas ${ }^{(12)}$.

\section{CARDIOVASCULAR DISEASES IN PATIENTS RECEIVING STEROID THERAPY}

Cardiovascular complications are the most common cause of death in patients with Cushing's syndrome ${ }^{(11)}$. Mortality in these patients is $2-5$ times higher than in the general population ${ }^{(13)}$. There are many factors associated with steroid therapy that affect the risk of adverse effects. These primarily include therapy duration and the doses used as well as age, gender, regimen, smoking tobacco and baseline cholesterol ${ }^{(14)}$. The risk of complications is higher when the steroids are used continuously compared to intermittent therapy ${ }^{(11)}$.

Hypercortisolism predisposes to hypertension, diabetes mellitus, lipid disorders ${ }^{(15-17)}$, abdominal obesity and insulin resistance ${ }^{(18)}$. Complications resulting from hypercortisolaemia may resemble the metabolic syndrome ${ }^{(13)}$. Glucocorticosteroids increase glycogen, protein and triglyceride breakdown ${ }^{(19)}$. Their influence on changes in lipid metabolism depends on the dose and therapy duration ${ }^{(20)}$. They increase hepatic gluconeogenesis and reduce glucose uptake by the liver and adipose tissue ${ }^{(21)}$. They are also likely to cause changes in coagulation and fibrinolysis, by increasing the synthesis of fibrinogen and reducing the synthesis of plasminogen activator and phospholipase $\mathrm{A} 2^{(5)}$.

Fardet et al. showed that patients who developed steroid-induced iatrogenic Cushing's disease have the highest risk of cardiovascular diseases ${ }^{(3)}$. There may exist a va- hypertension, e.g. drug effects on the renin-angiotensinaldosterone system, the autonomic nervous system, mineralocorticoid activity and the effects on the synthesis of factors that regulate vascular width ${ }^{(13)}$. It is believed that the increase in blood pressure may also be the result of steroidinduced increased synthesis of erythropoietin ${ }^{(22)}$, increased sodium retention in the kidneys ${ }^{(19)}$ and increased volume of extracellular fluid ${ }^{(23)}$. It is worth stressing here that hypertension affects about $70-85 \%$ of patients with endogenous Cushing's syndrome compared to $20 \%$ of patients with exogenous disease ${ }^{(13)}$. Perhaps short-term therapy has no effects on hypertension. Such conclusions were drawn by Fardet et al. who showed no significant increase in hypertension during short-term steroid therapy ${ }^{(24)}$.

Souverein et al. found in their study that steroids increase the risk of heart failure and myocardial ischemia as well as that the risk increases with increasing doses ${ }^{(23)}$. According to some researchers, steroid therapy may also increase the thickness of the intima-media complex of the carotid arteries ${ }^{(25)}$. The data on the effects of steroids on stroke and transient cerebral ischaemia are contradictory ${ }^{(11)}$. Manson et al. showed that cerebrovascular events may be a complication of steroid therapy ${ }^{(14)}$. According to Souverein et al., steroid therapy can even reduce the risk of cerebrovascular events ${ }^{(23)}$. Patients after adrenalectomy due to Cushing's syndrome show improvement in various parameters, e.g. reduced blood pressure, improved diabetes control, and reduced body weight ${ }^{(26)}$, as shown in the study by Terzolo et al., which indirectly points to the negative effects of steroids on the cardiovascular system. The authors analysed patients' condition after successful surgical treatment due to Cushing's syndrome, and showed improved blood pressure control as well as metabolic compensation of diabetes (reduced glycated haemoglobin) ${ }^{(27)}$.

\section{STUDIES IN SELECTED PATIENT POPULATIONS}

A number of studies on the effects of steroid therapy in patients with certain conditions have been conducted. It should be noted that chronic inflammation also promotes the development of cardiovascular diseases, which are treated with steroids ${ }^{(28)}$.

Chester Wasko et al. demonstrated increased mortality among patients with rheumatoid arthritis who were on steroid therapy. However, concomitant use of disease-modifying drugs reduced this correlation ${ }^{(29)}$.

Davis et al. showed that glucocorticosteroids increase the risk of cardiovascular diseases in patients with rheumatoid arthritis, but only those with rheumatoid factor. The increased risk was observed for prednisone doses above $7.5 \mathrm{mg} / \mathrm{day}^{(30)}$. Kitterer et al. analysed the effects of steroid therapy on myocardial lipid accumulation in patients with rheumatic diseases and confirmed this relationship. The risk was significantly higher at doses above $7.5 \mathrm{mg}$ prednisone per day, with therapy duration of more than 6 months $s^{(31)}$. 
Many studies have been also conducted on the effects of inhaled glucocorticosteroids on systemic side effects. In their study, Loke et al. analysed literature data on the effects of inhaled glucocorticosteroid therapy used for the treatment of chronic obstructive pulmonary disease on the occurrence of complications. They found that observational studies point to a relationship between the therapy used and mortality due to cardiovascular diseases and myocardial infarction. However, these findings were not confirmed in randomised controlled trials ${ }^{(32)}$.

\section{ANABOLIC STEROIDS}

It also seems worth mentioning about the effects of anabolic steroids on the cardiovascular system. A number of studies have shown that the use of androgenic anabolic steroids may lead to ischaemic heart disease, arrhythmia and sudden cardiac death ${ }^{(33)}$. Other consequences of using these drugs include myocardial hypertrophy, lipid disorders ${ }^{(34)}$, and an increased risk of atherosclerosis. Myocardial hypertrophy may lead to arrhythmia, hypertension, myocardial infarction, sudden cardiac death ${ }^{(35)}$, increased blood clotting and a tendency to platelet aggregation. The disorders resolve after discontinuation of anabolic steroids. No coronary changes were found in some of the patients after myocardial infarction who received anabolic steroids, which may indicate that myocardial ischaemia was likely to result from vasospasm ${ }^{(36)}$. Researchers show that the use of anabolic steroids may also lead to diastolic dysfunction and increased red blood cell count, which predisposes to thrombosis ${ }^{(37)}$.

\section{OTHER COMPLICATIONS}

Other adverse effects of steroid therapy include oral candidiasis, weight gain, myopathy, osteoporosis, hyperglycaemia ${ }^{(38)}$, hypokalaemia ${ }^{(39)}$, mood disorders, adrenal suppression ${ }^{(40)}$, altered fat distribution, menstrual disorders and reduced libido. Furthermore, they increase the risk of cataract and glaucoma $^{(41,42)}$, and may cause growth retardation ${ }^{(43)}$.

\section{CONCLUSIONS}

The wide use of steroids in the treatment of various diseases and multiple adverse effects associated with their use should encourage a thorough analysis of the indications for therapy and careful monitoring during treatment. It is necessary to properly balance between effective steroid doses and doses that are least likely to cause complications. It should be also noted that steroids may cause adverse effects regardless of the route of administration. Caution is also necessary with topical steroids. Due to the described risk of complications of the above discussed therapy, patients receiving long-term therapy with high doses of glucocorticosteroids should undergo regular blood pressure check-ups and have their lipidogram controlled periodically ${ }^{(25)}$.

\section{Conflict of interest}

Authors do not report any financial or personal connections with other persons or organisations, which might negatively affect the contents of this publication and/or claim authorship rights to this publication.

\section{References}

1. Jacobs JW, Bijlsma JW: Innovative combination strategy to enhance effect and diminish adverse effects of glucocorticoids: another promise? Arthritis Res Ther 2009; 11: 105.

2. Liu D, Ahmet A, Ward L et al.: A practical guide to the monitoring and management of the complications of systemic corticosteroid therapy. Allergy Asthma Clin Immunol 2013; 9: 30.

3. Fardet L, Petersen I, Nazareth I: Risk of cardiovascular events in people prescribed glucocorticoids with iatrogenic Cushing's syndrome: cohort study. BMJ 2012; 345: e4928.

4. Ericson-Neilsen W, Kaye AD: Steroids: pharmacology, complications, and practice delivery issues. Ochsner J 2014; 14: 203-207.

5. Maxwell SR, Moots RJ, Kendall MJ: Corticosteroids: do they damage the cardiovascular system? Postgrad Med J 1994; 70 : 863-870.

6. van der Goes MC, Jacobs JW, Bijlsma JW: The value of glucocorticoid co-therapy in different rheumatic diseases - positive and adverse effects. Arthritis Res Ther 2014; 16 Suppl 2: S2.

7. Petersons CJ, Mangelsdorf BL, Thompson $\mathrm{CH}$ et al.: Acute effect of increasing glucocorticoid replacement dose on cardiovascular risk and insulin sensitivity in patients with adrenocorticotrophin deficiency. J Clin Endocrinol Metab 2014; 99: 2269-2276.

8. Chaudhry HS, Bhimji SS: Cushing Syndrome, StatPearls [Internet]. Treasure Island (FL), StatPearls Publishing 2018.

9. Paragliola RM, Papi G, Pontecorvi A et al.: Treatment with synthetic glucocorticoids and the hypothalamus-pituitary-adrenal axis. Int J Mol Sci 2017; 18: pii: E2201.

10. Decani S, Federighi V, Baruzzi E et al.: Iatrogenic Cushing's syndrome and topical steroid therapy: case series and review of the literature. J Dermatolog Treat 2014; 25: 495-500.

11. Nowak KM, Papierska L: Prevention and monitoring of the side effects of chronic corticosteroid therapy. Postępy Nauk Med 2014; 27: 852-859.

12. Coondoo A, Phiske M, Verma S et al.: Side-effects of topical steroids: a long overdue revisit. Indian Dermatol Online J 2014; 5: 416-425.

13. Isidori AM, Graziadio C, Paragliola RM et al.: The hypertension of Cushing's syndrome: controversies in the pathophysiology and focus on cardiovascular complications. J Hypertens 2015; 33: 44-60.

14. Manson SC, Brown RE, Cerulli A et al.: The cumulative burden of oral corticosteroid side effects and the economic implications of steroid use. Respir Med 2009; 103: 975-994.

15. Anagnostis P, Karras SN, Athyros VG et al.: Subclinical Cushing's syndrome and cardiovascular disease. Lancet Diabetes Endocrinol 2014; 2: 361.

16. Hunter RW, Ivy JR, Bailey MA: Glucocorticoids and renal $\mathrm{Na}^{+}$ transport: implications for hypertension and salt sensitivity. J Physiol 2014; 592: 1731-1744.

17. Ng MK, Celermajer DS: Glucocorticoid treatment and cardiovascular disease. Heart 2004; 90: 829-830.

18. Coelho MC, Santos CV, Vieira Neto L et al.: Adverse effects of glucocorticoids: coagulopathy. Eur J Endocrinol 2015; 173: M11-M21.

19. Walker BR: Glucocorticoids and cardiovascular disease. Eur J Endocrinol 2007; 157: 545-559.

20. Trence DL: Management of patients on chronic glucocorticoid therapy: an endocrine perspective. Prim Care 2003; 30: 593-605.

21. Pandya D, Puttanna A, Balagopal V: Systemic effects of inhaled corticosteroids: an overview. Open Respir Med J 2014; 8: 59-65.

22. Whitworth JA, Mangos GJ, Kelly JJ: Cushing, cortisol, and cardiovascular disease. Hypertension 2000; 36: 912-916. 
23. Souverein PC, Berard A, Van Staa TP et al.: Use of oral glucocorticoids and risk of cardiovascular and cerebrovascular disease in a population based case-control study. Heart 2004; 90: 859-865.

24. Fardet L, Nazareth I, Petersen I: Synthetic glucocorticoids and early variations of blood pressure: a population-based cohort study. J Clin Endocrinol Metab 2015; 100: 2777-2783.

25. Patt H, Bandgar T, Lila A et al.: Management issues with exogenous steroid therapy. Indian J Endocrinol Metab 2013; 17 (Suppl 3): S612-S617.

26. Bancos I, Alahdab F, Crowley RK et al.: Improvement of cardiovascular risk factors after adrenalectomy in patients with adrenal tumors and subclinical Cushing's syndrome: a systematic review and meta-analysis. Eur J Endocrin 2016; 175: R283-R295.

27. Terzolo M, Allasino B, Pia A et al.: Surgical remission of Cushing's syndrome reduces cardiovascular risk. Eur J Endocrinol 2014; 171: 127-136.

28. Bijlsma JWJ, Buttgereit F: Adverse events of glucocorticoids during treatment of rheumatoid arthritis: lessons from cohort and registry studies. Rheumatology (Oxford) 2016; 55 (Suppl 2): ii3-ii5.

29. Chester Wasko M, Dasgupta A, Ilse Sears G et al.: Prednisone use and risk of mortality in patients with rheumatoid arthritis: moderation by use of disease-modifying antirheumatic drugs. Arthritis Care Res (Hoboken) 2016; 68: 706-710.

30. Davis JM $3^{\text {rd }}$, Maradit Kremers H, Crowson CS et al.: Glucocorticoids and cardiovascular events in rheumatoid arthritis: a population-based cohort study. Arthritis Rheum 2007; 56: 820-830.

31. Kitterer D, Latus J, Henes J et al.: Impact of long-term steroid therapy on epicardial and pericardial fat deposition: a cardiac MRI study. Cardiovasc Diabetol 2015; 14: 130.

32. Loke YK, Kwok CS, Singh S: Risk of myocardial infarction and cardiovascular death associated with inhaled corticosteroids in COPD. Eur Respir J 2010; 35: 1003-1021.
33. Karila T: Adverse effects of anabolic androgenic steroids on the cardiovascular, metabolic and reproductive systems of anabolic substance abusers. Drug Research Unit, Department of Mental Health and Alcohol Research, National Public Health Institute, Helsinki 2003: 19-24.

34. Hausmann R: Long-term effects of anabolic-androgenic-steroid abuse. Morphological findings associated with fatal outcome. In: Tsokos M (ed.): Forensic Pathology Reviews, Vol. 2. Humana Press Inc., Totowa, NJ 2005: 273-289.

35. van Amsterdam J, Opperhuizen A, Hartgens F: Adverse health effects of anabolic-androgenic steroids. Regul Toxicol Pharmacol 2010; 57: 117-123.

36. Payne JR, Kotwinski PJ, Montgomery HE: Cardiac effects of anabolic steroids. Heart 2004; 90: 473-475.

37. Deligiannis AP, Kouidi EI: Cardiovascular adverse effects of doping in sports. Hellenic J Cardiol 2012; 53: 447-457.

38. Fsadni CJ: A study on the management of corticosteroid side effects in cancer patients. The Journal of the Malta College of Family Doctors 2015; 4: 18-30.

39. Stanbury RM, Graham EM: Systemic corticosteroid therapy side effects and their management. Br J Ophthalmol 1998; 82: 704-708.

40. Aulakh R, Singh S: Strategies for minimizing corticosteroid toxicity: a review. Indian J Pediatr 2008; 75: 1067-1073.

41. Saag KG: Short-term and long-term safety of glucocorticoids in rheumatoid arthritis. Bull NYU Hosp Jt Dis 2012; 70 Suppl 1: 21-25.

42. Longui CA: Glucocorticoid therapy: minimizing side effects. J Pediatr (Rio J) 2007; 83 (Suppl): S163-S177.

43. Cruz-Topete D, Cidlowski JA: One hormone, two actions: antiand pro-inflammatory effects of glucocorticoids. Neuroimmunomodulation $2015 ; 22: 20-32$. 